\title{
Differential effects of resveratrol and novel resveratrol derivative, HS-1793, on endoplasmic reticulum stress-mediated apoptosis and Akt inactivation
}

\author{
HEE JUNG UM ${ }^{1}$, JAE HOON BAE ${ }^{2}$, JONG-WOOK PARK ${ }^{1}$, HONGSUK SUH ${ }^{3}$, \\ NA YOUNG JEONG ${ }^{4}$, YOUNG HYUN YOO ${ }^{4}$ and TAEG KYU KWON ${ }^{1}$
}

\begin{abstract}
${ }^{1}$ Department of Immunology and ${ }^{2}$ Department of Physiology, School of Medicine, Keimyung University, 194 DongSan-Dong Jung-Gu, Taegu 700-712; ${ }^{3}$ Department of Chemistry and Chemistry Institute for Functional Materials, Pusan National University; ${ }^{4}$ Department of Anatomy and Cell Biology, Dong-A University, College of Medicine and Medical Science Research Center, Busan 602-714, South Korea
\end{abstract}

Received September 23, 2009; Accepted December 18, 2009

DOI: 10.3892/ijo_00000581

\begin{abstract}
Since resveratrol (3,4',5 tri-hydroxystilbene), which has been shown to inhibit multistage carcinogenesis, is not a potent cytotoxic compound, several studies were undertaken to obtain synthetic analogues of resveratrol with potent activity. We previously reported that a resveratrol derivative HS-1793 exhibits stronger antitumor effects than resveratrol in several cancer cell types. The present study was undertaken to reveal precise mechanism by which HS-1793 induces cell death. The induction of CCAAT/enhancerbinding protein-homologous protein $(\mathrm{CHOP})$ and glucoseregulated protein (GRP)-78, and ER stress-specific XBP1 splicing were found in HT29 human colon carcinoma cells treated with resveratrol. Conversely, these manifestations were not observed in HT29 cells treated with HS-1793. Inhibition of caspase-4 activity by z-LEVD-fmk significantly reduced the induction of apoptosis by resveratrol but not by HS-1793. These findings suggest that HS-1793, contrary to resveratrol, does not induce ER stress-mediated apoptosis. Importantly, we observed that HS-1793 but not resveratrol decreased phosphorylated Akt level. We also demonstrated that HS-1793, compared to resveratrol, exerted more effective apoptosis inducing activity in Akt-activated cells. Taken together, the stronger antitumor activity of HS1793 originates, at least in part, from its ability for Akt inactivation.
\end{abstract}

Correspondence to: Dr Taeg Kyu Kwon, Department of Immunology, School of Medicine, Keimyung University, 194 DongSanDong Jung-Gu, Taegu 700-712, South Korea

E-mail: kwontk@dsmc.or.kr

Key words: resveratrol derivative, endoplasmic reticulum stress, apoptosis, Akt, CHOP

\section{Introduction}

Resveratrol (3,4',5 tri-hydroxystilbene) is a phytochemical known to be partly responsible for the cardioprotective effects of red wine due to a variety of its biological activities $(1,2)$. Resveratrol has been shown to exert chemopreventive effects against cancer based on its inhibition of cellular events associated with tumor initiation, promotion and progression in a variety of cell culture systems and animal models (3). Resveratrol is also able to activate mitochondria or ER stress-mediated apoptosis and non-apoptotic cell death (autophagocytosis) (4-6).

The endoplasmic reticulum (ER) is an organelle responsible for protein synthesis and modification, and storage of calcium $(7,8)$. ER dysfunction results in a stressful condition, called ER stress. The key players of the unfolded protein response (UPR) are three chronologically-activated ER resident-signaling proteins: protein kinase-like ER-resident kinase (PERK), inositol requiring 1 (Ire1) and activating transcription factor-6 (ATF-6) (9-12). Prolonged or severe ER stress is widely considered to trigger apoptosis. Several pro-apoptotic factors and signaling pathways, including CCAAT/enhancer-binding protein-homologous protein (CHOP), pro-apoptotic Bcl-2 family members, caspase-12 and c-Jun N-terminal kinase (JNK) have been shown to be involved in ER stress-induced cell death (13-16).

However, the concentration of resveratrol required to exert chemopreventive effects $(40-200 \mu \mathrm{M})$ is relatively high (17). Therefore, developing more potent derivative of resveratrol may provide a feasible means of achieving an effective physiologic concentration. Recently, we reported that a novel resveratrol derivative, HS-1793, is more potent than resveratrol and overcomes the resistance conferred by Bcl-2 (18). However, the precise mechanism by which HS1793 induces cell death is not fully understood. The aim of this study was to determine the capacity of HS-1793 to induce apoptosis and identify the biochemical mechanisms of this induction as well as novel target(s) including Akt signaling pathways in a cancer cells. The present study was 
undertaken to reveal precise mechanism by which HS-1793 induces cell death, focusing on ER stress pathway and Akt activation.

\section{Materials and methods}

Cells and materials. HT29, Caki and U937 cells were obtained from the American Type Culture Collection (ATCC; Rockville, MD). The culture medium used throughout these experiments was Dulbecco's modified Eagle's medium (DMEM), containing 10\% fetal calf serum (FCS), $20 \mathrm{mM}$ HEPES buffer and $100 \mu \mathrm{g} / \mathrm{ml}$ gentamicin. Resveratrol was purchased from Biomol (Biomol Research Laboratories Inc. PA, USA). The resveratrol derivative HS-1793 was synthesized and characterized as described previously by us (18). Other chemicals were obtained from Sigma Chemical Co. (St. Louis, MO). Anti-CHOP, anti-PARP, anti-caspase-3, antiGRP78, anti-Ref-1 and anti-ERK antibodies were purchased from Santa Cruz Biotechnology Inc. (Santa Cruz, CA, USA). Anti-phospho-Akt and anti-Akt were purchased from New England Biolabs. Anti-XBP1 antibody was purchased from Biolegend (San Diego, CA).

Western blotting. Cellular lysates were prepared by suspending $1 \times 10^{6}$ cells in $100 \mu \mathrm{l}$ of lysis buffer $(137 \mathrm{mM}$ $\mathrm{NaCl}, 15 \mathrm{mM}$ EGTA, $0.1 \mathrm{mM}$ sodium orthovanadate, $15 \mathrm{mM}$ $\mathrm{MgCl}_{2}, 0.1 \%$ Triton X-100, $25 \mathrm{mM}$ MOPS, $100 \mu \mathrm{M}$ phenylmethylsulfonylfluoride and $20 \mu \mathrm{M}$ leupeptin, adjusted to $\mathrm{pH}$ 7.2). The cells were disrupted by sonication and extracted at $4^{\circ} \mathrm{C}$ for $30 \mathrm{~min}$. The proteins were electrotransferred to immobilon-P membranes (Millipore Corporation, Bedford, MA, USA). Detection of specific proteins was carried out with an ECL Western blotting kit according to the manufacturer's instructions.

Cell count and flow cytometry analysis. Cell counts were performed using a hemocytometer. Approximately $1 \times 10^{6}$ HT29 cells were suspended in $100 \mu \mathrm{l}$ of PBS and $200 \mu \mathrm{l}$ of $95 \%$ ethanol were added while vortexing. The cells were incubated at $4^{\circ} \mathrm{C}$ for $1 \mathrm{~h}$, washed with PBS and resuspended in $250 \mu \mathrm{l}$ of $1.12 \%$ sodium citrate buffer $(\mathrm{pH} 8.4)$ together with $12.5 \mu \mathrm{g}$ of RNase. Incubation was continued at $37^{\circ} \mathrm{C}$ for $30 \mathrm{~min}$. The cellular DNA was then stained by applying $250 \mu \mathrm{l}$ of propidium iodide $50 \mu \mathrm{g} / \mathrm{ml}$ ) for $30 \mathrm{~min}$ at room temperature. The stained cells were analyzed by fluorescentactivated cell sorting (FACS) on a FACScan flow cytometer for relative DNA content based on red fluorescence.

RNA isolation and reverse transcriptase-polymerase chain reaction $(R T-P C R)$. Total cellular RNA was extracted from cells using the TRIzol reagent (Life Technologies). A cDNA was synthesized from $2 \mu \mathrm{g}$ of total RNA using M-MLV reverse transcriptase (Gibco-BRL, Gaithersburg, MD). The cDNA for XBP1 was amplified by PCR with specific primers: XBP1 (sense) 5'-CCTTGTAGTTGAGAACCAGG-3' and (anti-sense) 5'-GGGGCTTGGTATATATGTGG-3'. PCR amplification was carried out as follows: $1 \mathrm{X}\left(94^{\circ} \mathrm{C}, 3 \mathrm{~min}\right)$; $30 \mathrm{X}\left(94^{\circ} \mathrm{C}, 45 \mathrm{sec} ; 57^{\circ} \mathrm{C}, 45 \mathrm{sec}\right.$; and $\left.72^{\circ} \mathrm{C}, 1 \mathrm{~min}\right)$; and $1 \mathrm{X}$ $\left(72^{\circ} \mathrm{C}, 10 \mathrm{~min}\right)$. PCR products were analyzed by agarose gel electrophoresis and visualized by ethidium bromide.
Expression of constitutively active Akt. Akt-overexpressing U937 cells were generated using a Myc-His-tagged mouse Aktl (activated) under the control of the cytomegalovirus promoter (Upstate Biotechnology), respectively. U937 cells $\left(2 \times 10^{6}\right.$ cells $\left./ \mathrm{ml}\right)$ in RPMI-1640 medium were transfected by preincubation with $15 \mu \mathrm{g}$ Akt plasmid for $10 \mathrm{~min}$ at room temperature followed by electroporation at $500 \mathrm{~V}, 700 \mu \mathrm{F}$. The sample was immediately placed on ice for $10 \mathrm{~min}$, and after $10 \mathrm{ml}$ complete medium was added, the cells were incubated at $37^{\circ} \mathrm{C}$ for $24 \mathrm{~h}$. The cells were selected in a medium containing $0.7 \mu \mathrm{g} / \mathrm{ml}$ geneticin (G418 sulfate) for 4 weeks. Single cell clones were obtained by limiting dilution and subsequently analyzed for an increase in Akt protein expression relative to the identically cloned empty vector control.

Preparation of nuclear extract. After required treatment, HT29 cells were trypsinized and suspended in low salt buffer (20 mM Tris at $\mathrm{pH} 4.0,20 \mathrm{mM} \mathrm{KCl}, 1.5 \mathrm{mM} \mathrm{MgCl}, 1 \mathrm{mM}$ DTT, 25\% glycerol, $0.2 \mathrm{mM}$ EDTA, $10 \mu \mathrm{g} / \mathrm{ml}$ leupeptin and $5 \mu \mathrm{g} / \mathrm{ml}$ aprotinin). After incubation on ice for $30 \mathrm{~min}$, the cells were then centrifuged at 2,500 rpm for $3 \mathrm{~min}$ to obtained nuclear pellet. The high salt buffer $(20 \mathrm{mM}$ Tris at $\mathrm{pH} 4.0,1.2 \mathrm{M} \mathrm{KCl}, 1.5 \mathrm{mM} \mathrm{MgCl} 2,1 \mathrm{mM}$ DTT, $25 \%$ glycerol, $0.2 \mathrm{mM}$ EDTA, $10 \mu \mathrm{g} / \mathrm{ml}$ leupeptin and $5 \mu \mathrm{g} / \mathrm{ml}$ aprotinin) was added followed by rotating the nuclei for $30 \mathrm{~min}$ at $4^{\circ} \mathrm{C}$. The resulting lysates were then centrifuged at $12,000 \mathrm{rpm}$ at $4^{\circ} \mathrm{C}$ for $5 \mathrm{~min}$. The supernatants were collected as nuclear extract.

Measurement of intracellular calcium concentration $\left(\left[\mathrm{Ca}^{2+}\right]_{i}\right)$. Microfluorescent imaging of intracellular calcium concentration $\left(\left[\mathrm{Ca}^{2+}\right]_{\mathrm{i}}\right)$ was performed on cultured HT29 cells loaded with the calcium indicator dye fura-2/AM. Some of the procedures used in calcium imaging in this experiment have been described (19). Fura-2/AM $(3 \mu \mathrm{M})$ was added to HT29 cells bathed in $1.8 \mathrm{mM} \mathrm{Ca}^{2+}$ containing physiological saline solution at room temperature for $30 \mathrm{~min}$ followed by a 30-min wash in dye-free saline solution to allow esterase conversion to free form of fura-2. Cover slips were placed on the stage of an inverted microscope and imaging was performed with a dual-wavelength system (Intracellular Imaging, Cincinnati, OH, USA). $\left[\mathrm{Ca}^{2+}\right]_{\mathrm{i}}$ was calculated as the relationship between the ratio of emissions at $510 \mathrm{~nm}$ from excitation at 340 and $380 \mathrm{~nm}$, respectively. Ratio images were processed every $5 \mathrm{sec}$ and converted to $\left[\mathrm{Ca}^{2+}\right]_{\mathrm{i}}$ as compared to a range of such ratios obtained by measurement of fura- 2 in the presence of known concentration of calcium (Calcium Calibration Buffer Kit, Molecular Probe, Eugene, OR, USA). Each experimental data point represents the mean $\left[\mathrm{Ca}^{2+}\right]_{\mathrm{i}}$ calculated from at least 12 individually measured cells from three separate cultures. All imaging experiments were done at room temperature $\left(20-22^{\circ} \mathrm{C}\right)$.

\section{Results}

Cellular features characteristic of apoptosis in HT29 cells exposed to resveratrol or HS-1793. HT29 (human colon carcinoma) cells were treated with various concentrations of resveratrol or HS-1793. Apoptosis was determined in HT29 

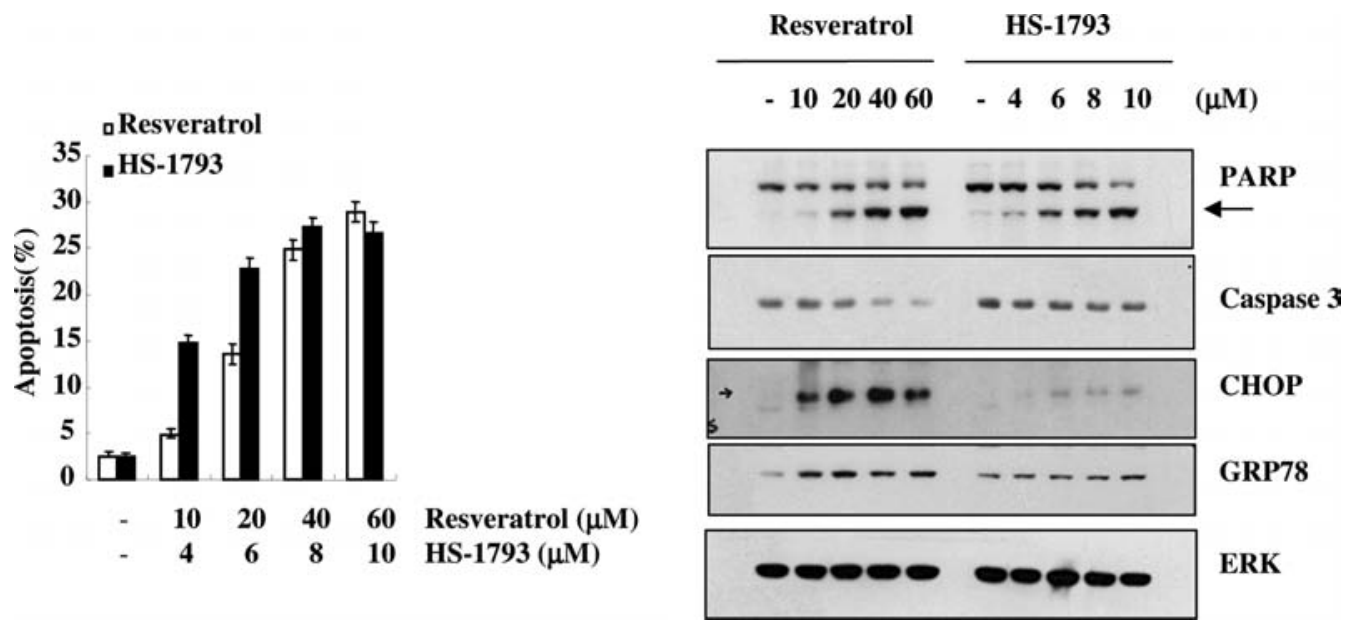

Figure 1. Resveratrol and HS-1793 induces apoptosis in HT-29 cells. HT29 cells were treated for $24 \mathrm{~h}$ with the indicated concentrations of resveratrol or HS-1793 and then evaluated for DNA content after propidium iodide staining. The fraction of apoptotic cells is shown as indicated. Data are mean values obtained from three independent experiments and bars represent standard deviation. HT29 cells treated as above were harvested in lysis buffer and equal amounts of cell lysates $(40 \mu \mathrm{g})$ were subjected to electrophoresis and analyzed by Western blot for PARP, caspase 3, CHOP and GRP78. The proteolytic cleavages of PARP are indicated by an arrow. Anti-ERK antibodies serve as control for the loading of protein level.
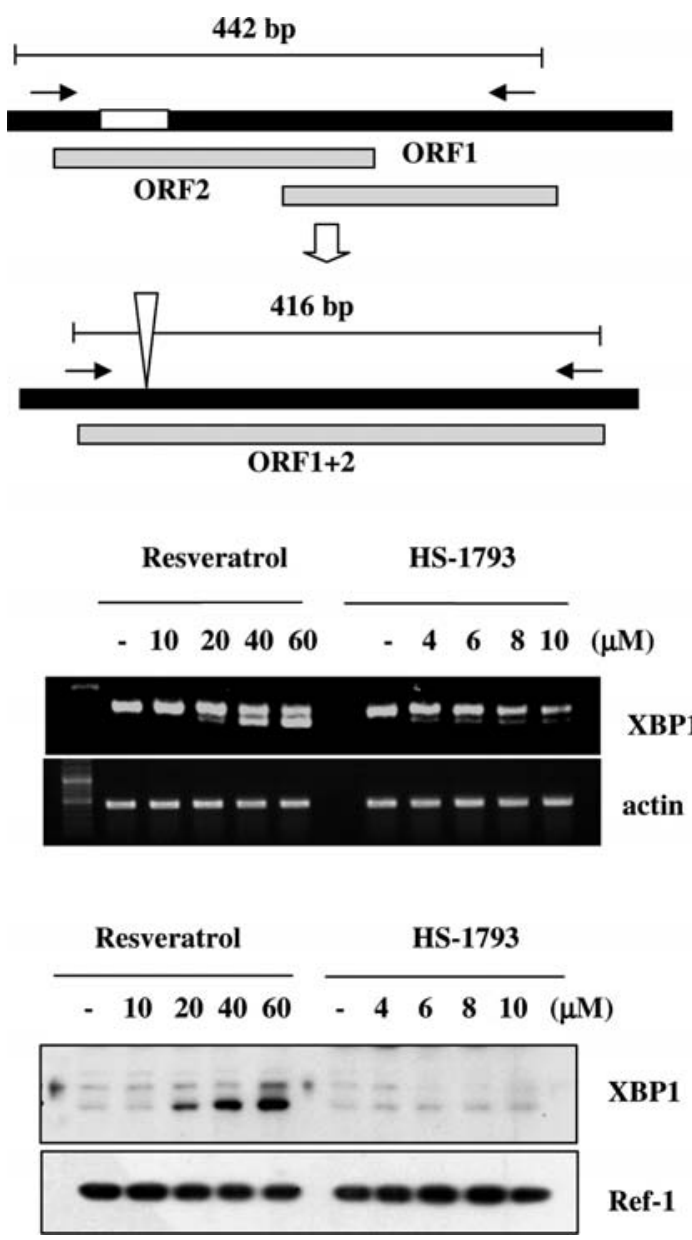

Figure 2. Effect of resveratrol and HS-1793 on splicing of XBP1 mRNA and expression levels of XBP1 protein. HT29 cells were treated with the indicated concentrations of resveratrol or HS-1793 for $14 \mathrm{~h}$. Total RNA was isolated and RT-PCR analysis was performed as described in Materials and methods. The 416-bp form appearing in treated cells represents the spliced form of the mRNA. After HT29 cells were treated with the indicated concentrations, nuclear extracts were analyzed for XBP1 and Ref-1 by Western blotting as described in Materials and methods. cells using flow cytometry analysis demonstrating hypodiploid DNA. As shown in Fig. 1, treatment with resveratrol or HS-1793 in HT29 cells resulted in a markedly increased accumulation of sub-G1 phase in a dose-dependent manner. These data indicated that HS-1793 is more potent than resveratrol. Because cells undergoing apoptosis execute the death program by activating caspases and cleavage of PARP, we analyzed expression levels of pro-caspase- 3 and cleavage of PARP. As shown in Fig. 1, exposure to both resveratrol and HS-1793 led to a reduction of the 32-kDa precursor, accompanied by cleavage of PARP. Activation of ATF6 and the subsequent induction of GRP78 and CHOP are known to be one of the hallmarks of the ER stress responses (8). Thus, we examined the effect of resveratrol or HS-1793 on the expression of GRP78 and CHOP by Western blotting. As shown in Fig. 1, treatment with resveratrol induced the expression of GRP78 and CHOP protein in a dose-dependent manner but not with HS-1793.

HS-1793 does not induce splicing of XBP1 mRNA. During ER stress, the mRNA encoding the transcription factor XBP1 is spliced by the endoribonuclease IRE1 that results in the removal of 26-nucleotide intron and a translational frame shift $(12,20)$. The spliced XBP1 mRNA is translated into a functional transcriptional activator $(12,20)$. Thus, we examine the alternative splicing of XBP1 mRNA using RT-PCR and Western blotting. As shown in Fig. 2, resveratrol induced the splicing of XBP1 mRNA and expression of spliced XBP1 protein. However, HS-1793 did not induce splicing of XBP1 mRNA and expression of spliced XBP1 protein.

Role of caspase-4 in resveratrol-induced apoptosis of HT-29 cells. To corroborate that apoptosis induced by HS-1793 is not ER stress-mediated, we examined the effect of a pancaspase inhibitor z-VAD-fmk and a caspase-4-specific inhibitor z-LEVD-fmk. Induction of apoptosis by resveratrol was significantly reduced not only z-VAD-fmk but also by z-LEVD-fmk as determined by DNA hypoploidy (Fig. 3A). 
A

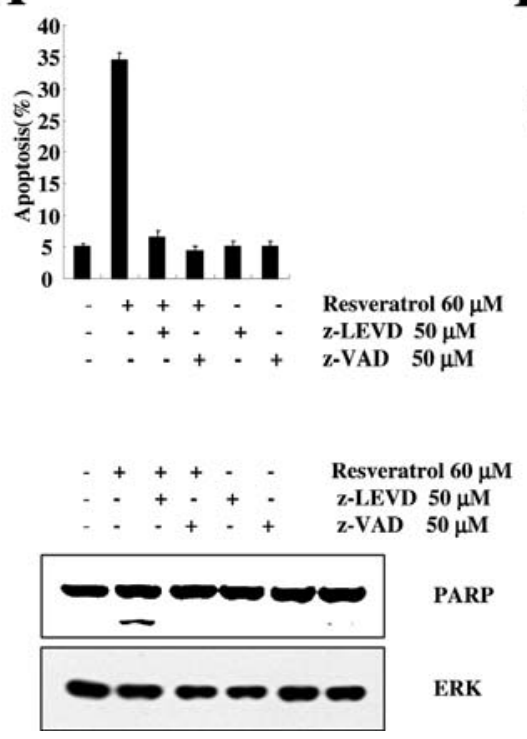

B
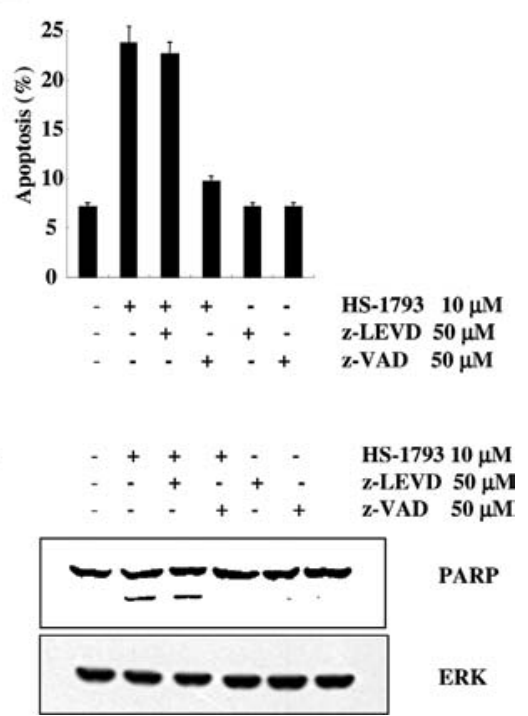

Figure 3. Effect of caspase-4 inhibitor on resveratrol- and HS-1793-induced apoptosis. (A) HT29 cells were incubated with z-VAD-fmk (pan-caspase inhibitor; $50 \mu \mathrm{M}$ ), z-LEVD-fmk (caspase-4 inhibitor; $50 \mu \mathrm{M}$ ) or solvent for $1 \mathrm{~h}$ before challenge with resveratrol $(60 \mu \mathrm{M})$ for $24 \mathrm{~h}$. Apoptosis was analyzed as a sub-G1 fraction by FACS. Equal amounts of cell lysates $(40 \mu \mathrm{g})$ were resolved by SDS-PAGE, transferred to nitrocellulose membrane and probed with anti-PARP or with anti-ERK antibody to serve as control for the loading of protein level. (B) HT29 cells were incubated with z-VAD-fmk (pan-caspase inhibitor; $50 \mu$ M), z-LEVD-fmk (caspase-4 inhibitor; $50 \mu \mathrm{M}$ ) or solvent for $1 \mathrm{~h}$ before challenge with HS-1793 (10 $\mu \mathrm{M})$ for $24 \mathrm{~h}$. Apoptosis was analyzed as a sub-G1 fraction by FACS. Equal amounts of cell lysates $(40 \mu \mathrm{g})$ were resolved by SDS-PAGE, transferred to nitrocellulose membrane and probed with anti-PARP or with anti-ERK antibody to serve as control for the loading of protein level. A representative study is shown; two additional experiments yielded similar results.
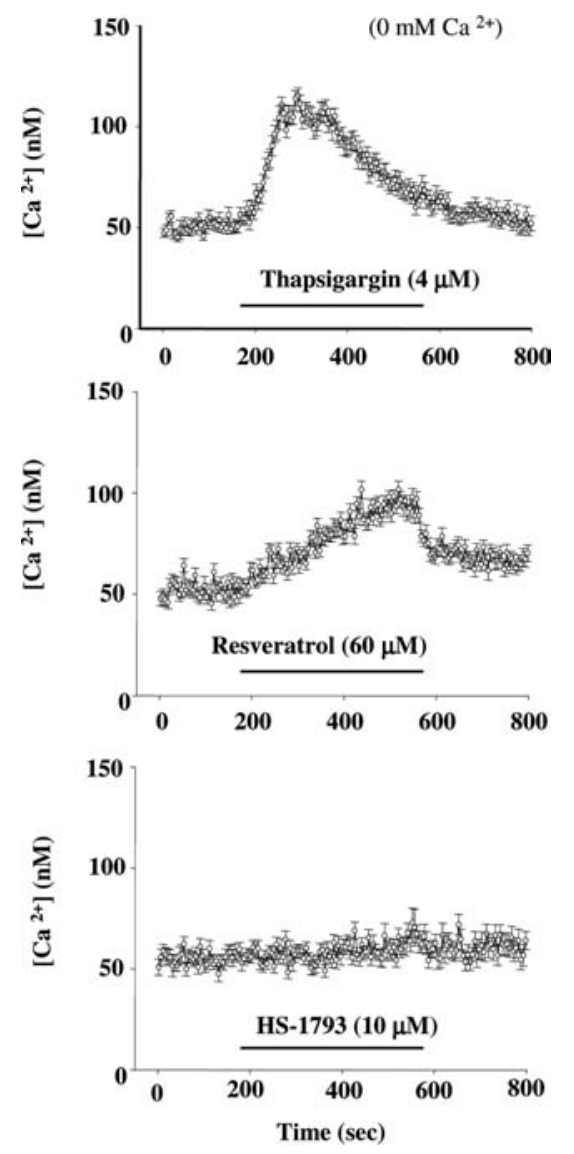

Figure 4. Effect of thapsigargin, resveratrol and HS-1793 on intracellular calcium concentration $\left(\left[\mathrm{Ca}^{2+}\right]_{\mathrm{i}}\right)$ in HT29 cells. Thapsigargin $(4 \mu \mathrm{M})$ and resveratrol produced the increase in $\left(\left[\mathrm{Ca}^{2+}\right]_{i}\right)$, but not HS-1793. The experiments were performed in $\mathrm{Ca}^{2+}$-free medium. Data are the mean $\pm \mathrm{SEM}$ of measurement made in 40-50 cells of three separate experiments.
In addition, both z-LEVD-fmk and z-VAD-fmk prevented cleavage of PARP in HT-29 cells treated with resveratrol (Fig. 3A). However, HS-1793-induced apoptosis was inhibited by z-VAD-fmk, but not z-LEVD-fmk. Taken together, our results suggest that resveratrol-induced apoptosis is associated with its ability to cause ER stress, but not HS1793.

Resveratrol induces depletion of intracellular $\mathrm{Ca}^{2+}$ stores. There is abundant evidence that dysregulation of $\mathrm{Ca}^{2+}$ homeostasis is critically involved in ER stress-mediated apoptosis $(7,8)$. Thus, we next tested the effect of resveratrol or HS1793 on cytosolic calcium in HT29 cells. As shown in Fig. 4, whereas resveratrol or thapsigargin (selective inhibitor of ER $\mathrm{Ca}^{2+}$-ATPase) significantly elevated $\left[\mathrm{Ca}^{2+}\right]_{\mathrm{i}}$, HS-1793 did not induce depletion of intracellular $\mathrm{Ca}^{2+}$ stores.

HS-1793 induces down-regulation of Akt phosphorylation. Although we undertook the present study to dissect the mechanism underlying the potent apoptosis inducing activity of HS-1793, the above results suggest that whereas resveratrol induces, at least in part, apoptosis on HT-29 cells in ER stress-mediated pathway, apoptosis inducing activity of HS1793 is not associated with its ability to cause ER stress. Thus, we next focused the activity of HS-1793 on Akt activation. Since protein kinase B (PKB/Akt) is a serine/threonine kinase that has been established as an important intracellular signaling in regulating cell survival (21). As shown in Fig. 5A, HT-29 cells treated with HS-1793 have no effect on steady state levels of total Akt protein, whereas phosphorylated Akt levels were decreased significantly in a time-dependent manner whereas resveratrol did not alter the level of phos- 
A

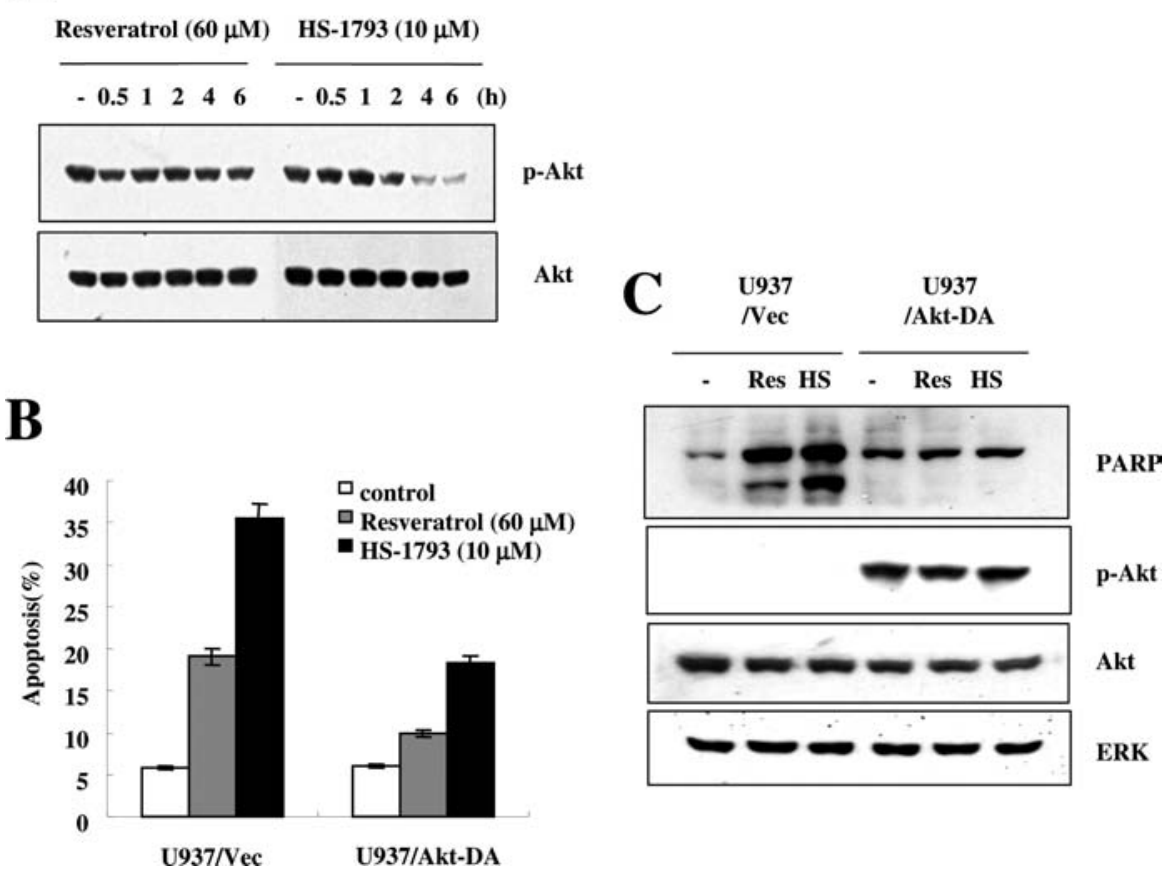

Figure 5. Akt pathway plays a role in regulating HS-1793-induced apoptosis of U937 cells. (A) HS-1793 induced down-regulation of pAkt in a timedependent manner. HT29 cells were treated with resveratrol $(60 \mu \mathrm{M})$ or HS-1793 $(10 \mu \mathrm{M})$ for the indicated time points. Western blot analysis was performed. (B) Ectopic expression of constitutive active Akt reduces withaferin A-induced apoptosis. U937/vector and U937/ DA-Akt cells were treated with resveratrol or HS-1793 for $20 \mathrm{~h}$ and their DNA content was measured after propidium iodide staining. Apoptosis was analyzed as the sub-G1 fraction by FACS. (C) Whole cell lysates obtained from U937/vector and U937/DA-Akt cells were subjected to SDS-PAGE, transferred to membranes and immunoblotted using PARP, anti-Akt, anti-phospho-Akt and anti-ERK antibodies as indicated.
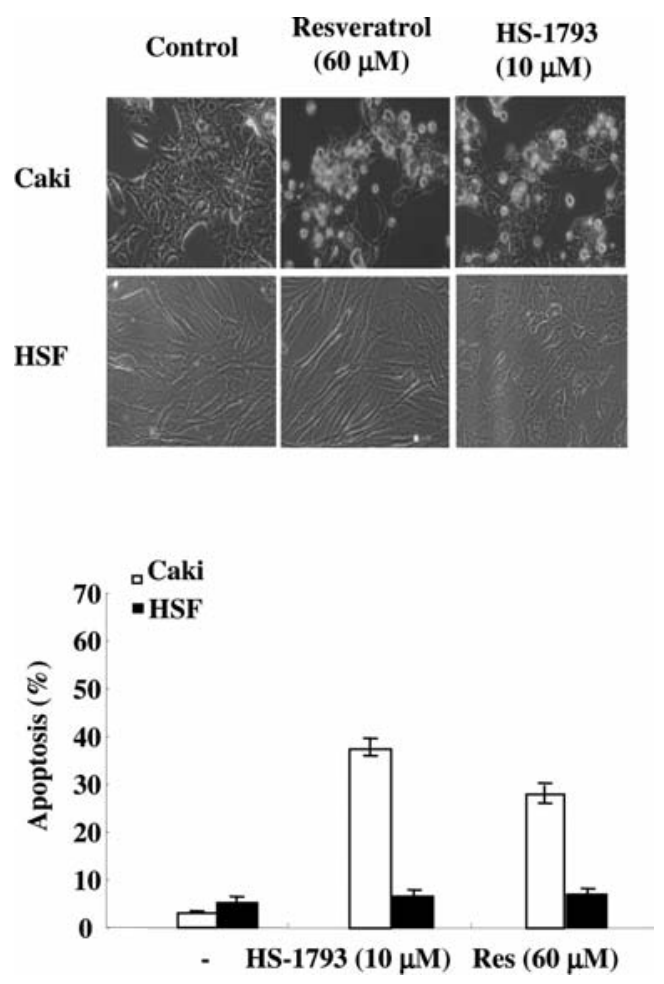

Figure 6. Morphology of normal and Caki cells after treatment by resveratrol and HS-1793. Caki and normal skin fibroblast cells (HSF) were treated with vehicle, $60 \mu \mathrm{M}$ resveratrol and $10 \mu \mathrm{M}$ HS-1793 for $24 \mathrm{~h}$. The morphology of cells was determined by interference light microscopy (magnification, x200) (upper panel). Apoptosis was analyzed as a sub-G1 fraction by FACS. Data are mean values obtained from three independent experiments and bars represent standard deviation (lower panel). phorylated Akt. To further evaluate the modulation of Akt signaling by HS-1793, we employed U937/vector and U937/ DA-Akt cells generated by transfection of the constitutively active Myc-tagged form of Akt (myr-Akt). U937/vector and U937/myr-Akt cells were exposed to HS-1793 or resveratrol for $20 \mathrm{~h}$. HS-1793 treatment in U937/vector cells resulted in a markedly increased accumulation of sub-G1 phase. In contrast, expression of constitutively active Akt reduced HS-1793-induced accumulation of sub-G1 phase (Fig. 5B). HS-1793, compared to resveratrol, more effectively induced apoptosis in Akt-activated cells. We next analyzed the expression levels of phosphor-Akt, Akt and PARP cleavage in U937/vector and U937/myr-Akt cells exposed to HS-1793 or resveratrol. As shown in Fig. 5C, cleavage of PARP was prevented by ectopic expression of constitutively active Akt. Taken together, these results indicate that HS-1793 induces apoptosis via modulating the Akt signaling pathway.

The effect of HS-1793 or resveratrol on normal cell growth. To this end, we investigated whether HS-1793 or resveratrol affects the induction of apoptosis in normal human skin fibroblast (HSF) cells. The apoptotic characteristics, such as cell shrinkage, apoptotic bodies and detachment from the plate, were frequently observed in Caki cells treated with HS-1793 or resveratrol (Fig. 6). However, HSF cells were resistant to HS-1793 or resveratrol. Furthermore, their morphological changes and viability were not significantly affected by HS-1793 or resveratrol, demonstrating that HS-1793 or resveratrol preferentially induced apoptosis in cancer cells, sparing normal cells. 


\section{Discussion}

Although the cancer chemopreventive agent, resveratrol, has been shown to induce apoptosis in a variety of human cancer cell lines $(1,2)$, current research on the use of resveratrol as potential cancer chemoprevention agent is limited, since resveratrol is not a potent cytotoxic agent when compared with other chemotherapeutic drugs. In an attempt to determine whether chemical modification of the stilbene backbone of resveratrol may further enhance its biological activity, our previous studies showed that HS-1793, a novel resveratrol derivative, may be superior to natural resveratrol as a candidate for chemoprevention agent (18). In addition, HS-1793 induces apoptosis and overcomes the resistance conferred by Bcl-2 in U937 cells through down-regulation of 14-3-3 (18). The present study provides important evidence to support the HS-1793, contrary to resveratrol, it does not induce apoptosis via ER stress-mediated pathway. In addition, we found that HS-1793 was substantially more potent than resveratrol at down-regulation of Akt phosphorylation.

Known ER stresses include calcium store depletion, inhibition of glycosylation, reduction of disulfide bonds and overexpression of mutant proteins (22-24). The present study demonstrates that induction of ER stress-related proteins may be involved in resveratrol-induced apoptosis. 1) Resveratrol induces GRP78 and CHOP expression. CHOP is one of the highest inducible genes during ER stress (8). 2) Resveratrol induces splicing of XBP1 mRNA. Under ER stress conditions, XBP1 mRNA is processed by unconventional splicing and translated into a functional transcription factor $(12,20) .3)$ Inhibition of caspase-4 activity by z-LEVD-fmk significantly reduced resveratrol-induced apoptosis. 4) Resveratrol induces depletion of intracellular $\mathrm{Ca}^{2+}$ stores. However, HS-1793 did not induce ER stress-mediated apoptosis. The fact that resveratrol, but not HS-1793, exhibits differential ER stress-induced apoptotic effect suggests that structure-related mechanisms may be crucial in ER stress. Resveratrol is unstable and its stilbene double bonds are readily oxidized. HS-1793 does not contain this unstable double bond.

$\mathrm{Akt} / \mathrm{PKB}$ is a serine/threonine protein kinase that functions as a critical regulator of cell survival and proliferation (2527). We have shown that Akt is dephosphorylated after treatment with HS-1793, but not resveratrol. Ectopic expression of constitutively active Akt reduces HS-1793induced apoptosis. These results suggest that HS-1793induced apoptosis is associated with Akt inactivation. The ability of Akt to promote cell survival is based on its ability to phosphorylate on residues necessary for their inactivation of several proapoptotic proteins, including Bad, caspase-9, transcription factors of the forkhead family and IKK (28-30).

The identification of the nature of these structures may help to resolve the ER stress-mediated apoptotic mechanisms induced by resveratrol in cancer cells. These data suggest that ER stress may be of importance for the cytotoxic activity of resveratrol. However, how resveratrol causes ER stress in cancer cells is not clear. Interestingly, HS-1793 did not induce ER stress-mediated apoptosis, but it caused down-regulation of Akt phosphorylation. In addition, other targets of HS-1793 particularly could be further investigated by microarray. Therefore, further study on the resveratrol derivative is required to delineate exactly its reactions inside the cells, to explain its biological effects.

\section{Acknowledgements}

This work was supported by the Korea Science and Engineering Foundation (KOSEF) (R13-2002-028-03001-0).

\section{References}

1. Frémont L: Biological effects of resveratrol. Life Sci 66: 663-673, 2000.

2. Gusman J, Malonne $\mathrm{H}$ and Atassi G: A reappraisal of the potential chemopreventive and chemotherapeutic properties of resveratrol. Carcinogenesis 22: 1111-1117, 2001.

3. Jang M, Cai L, Udeani GO, Slowing KV, Thomas CF, Beecher CW, Fong HH, Farnsworth NR, Kinghorn AD, Mehta RG, Moon RC and Pezzuto JM: Cancer chemopreventive activity of resveratrol, a natural product derived from grapes. Science 275: 218-220, 1997.

4. Park JW, Choi YJ, Suh SI, Baek WK, Suh MH, Jin IN, Min DS, Woo JH, Chang JS, Passaniti A, Lee YH and Kwon TK: Bcl-2 overexpression attenuates resveratrol-induced apoptosis in U937 cells by inhibition of caspase-3 activity. Carcinogenesis 22: 1633-1639, 2001.

5. Park JW, Woo KJ, Lee JT, Lim JH, Lee TJ, Kim SH, Choi YH and Kwon TK: Resveratrol induces pro-apoptotic endoplasmic reticulum stress in human colon cancer cells. Oncol Rep 18: 1269-1273, 2007.

6. Opipari AW Jr, Tan L, Boitano AE, Sorenson DR, Aurora A and Liu JR: Resveratrol-induced autophagocytosis in ovarian cancer cells. Cancer Res 64: 696-703, 2004.

7. Schröder M: Endoplasmic reticulum stress responses. Cell Mol Life Sci 65: 862-894, 2008.

8. Oyadomari S and Mori M: Roles of CHOP/GADD153 in endoplasmic reticulum stress. Cell Death Differ 11: 381-389, 2004.

9. Bertolotti A, Zhang Y, Hendershot LM, Harding HP and Ron D: Dynamic interaction of BiP and ER stress transducers in the unfolded-protein response. Nat Cell Biol 2: 326-332, 2000.

10. Haze K, Yoshida H, Yanagi H, Yura T and Mori K: Mammalian transcription factor ATF6 is synthesized as a transmembrane protein and activated by proteolysis in response to endoplasmic reticulum stress. Mol Biol Cell 10: 3787-3799, 1999.

11. Harding HP, Zhang Y and Ron D: Protein translation and folding are coupled by an endoplasmic-reticulum-resident kinase. Nature 397: 271-274, 1999.

12. Calfon M, Zeng H, Urano F, Till JH, Hubbard SR, Harding HP, Clark SG and Ron D: IRE1 couples endoplasmic reticulum load to secretory capacity by processing the XBP-1 mRNA. Nature 415: 92-96, 2002

13. Nakagawa T, Zhu H, Morishima N, Li E, Xu J, Yankner BA and Yuan J: Caspase-12 mediates endoplasmic-reticulumspecific apoptosis and cytotoxicity by amyloid-beta. Nature 403: 98-103, 2000.

14. Wang XZ, Lawson B, Brewer JW, Zinszner H, Sanjay A, Mi LJ, Boorstein R, Kreibich G, Hendershot LM and Ron D: Signals from the stressed endoplasmic reticulum induce C/EBPhomologous protein (CHOP/GADD153). Mol Cell Biol 16: 4273-4280, 1996.

15. Hetz CA: ER stress signaling and the BCL-2 family of proteins: from adaptation to irreversible cellular damage. Antioxid Redox Signal 9: 2345-2355, 2007.

16. Sekine Y, Takeda K and Ichijo H: The ASK1-MAP kinase signaling in ER stress and neurodegenerative diseases. Curr Mol Med 6: 87-97, 2006.

17. Gosslau A, Chen M, Ho CT and Chen KY: A methoxy derivative of resveratrol analogue selectively induced activation of the mitochondrial apoptotic pathway in transformed fibroblasts. $\mathrm{Br}$ J Cancer 92: 513-521, 2005.

18. Jeong SH, Jo WS, Song S, Suh H, Seol SY, Leem SH, Kwon TK and Yoo YH: A novel resveratrol derivative, HS1793, overcomes the resistance conferred by Bcl-2 in human leukemic U937 cells. Biochem Pharmacol 77: 1337-1347, 2009. 
19. McLarnon JG, Franciosi S, Wang X, Bae JH, Choi HB and Kim SU: Acute actions of tumor necrosis factor-alpha on intracellular $\mathrm{Ca}(2+)$ and $\mathrm{K}(+)$ currents in human microglia. Neuroscience 104: 1175-1184, 2001.

20. Yoshida H, Matsui T, Yamamoto A, Okada T and Mori K: XBP1 mRNA is induced by ATF6 and spliced by IRE1 in response to ER stress to produce a highly active transcription factor. Cell 107: 881-891, 2001

21. Tokunaga E, Oki E, Egashira A, Sadanaga N, Morita M, Kakeji Y and Maehara Y: Deregulation of the Akt pathway in human cancer. Curr Cancer Drug Targets 8: 27-36, 2008.

22. Lee AS: The glucose-regulated proteins: stress induction and clinical applications. Trends Biochem Sci 26: 504-510, 2001.

23. Pahl HL: Signal transduction from the endoplasmic reticulum to the cell nucleus. Physiol Rev 79: 683-701, 1999.

24. Kaufman RJ: Stress signaling from the lumen of the endoplasmic reticulum: coordination of gene transcriptional and translational controls. Genes Dev 13: 1211-1233, 1999.
25. Datta SR, Brunet A and Greenberg ME: Cellular survival: a play in three Akts. Genes Dev 13: 2905-2927, 1999.

26. Clark EA and Brugge JS: Integrins and signal transduction pathways: the road taken. Science 268: 233-239, 1995.

27. Segal RA and Greenberg ME: Intracellular signaling pathways activated by neurotrophic factors. Annu Rev Neurosci 19: 463-489, 1996.

28. Nicholson KM and Anderson NG: The protein kinase B/Akt signalling pathway in human malignancy. Cell Signal 14: 381-395, 2002.

29. Datta SR, Dudek H, Tao X, Masters S, Fu H, Gotoh Y and Greenberg ME: Akt phosphorylation of BAD couples survival signals to the cell-intrinsic death machinery. Cell 91: 231-241, 1997.

30. Nakamura N, Ramaswamy S, Vazquez F, Signoretti S, Loda M and Sellers WR: Forkhead transcription factors are critical effectors of cell death and cell cycle arrest downstream of PTEN. Mol Cell Biol 20: 8969-8982, 2000. 